\title{
Cyanide-Free Displacement Silver Plating Using Highly Concentrated Aqueous Solutions of Metal Chloride Salts
}

\section{AUTHOR(S):}

Adachi, Ken; Kitada, Atushi; Fukami, Kazuhiro; Murase, Kuniaki

\section{CITATION:}

Adachi, Ken ... [et al]. Cyanide-Free Displacement Silver Plating Using Highly Concentrated Aqueous Solutions of Metal Chloride Salts. Journal of The Electrochemical Society 2019, 166(10): D409-D414

ISSUE DATE:

2019-06-11

URL:

http://hdl.handle.net/2433/241762

\section{RIGHT:}

(c) The Author(s) 2019. Published by ECS. This is an open access article distributed under the terms of the Creative Commons Attribution 4.0 License (CC BY, http://creativecommons.org/licenses/by/4.0/), which permits unrestricted reuse of the work in any medium, provided the original work is properly cited. 


\title{
Cyanide-Free Displacement Silver Plating Using Highly Concentrated Aqueous Solutions of Metal Chloride Salts
}

\author{
Ken Adachi, $\odot$ Atushi Kitada, $\mathbb{1}^{\mathrm{z}}$ Kazuhiro Fukami, ${ }^{*}$ and Kuniaki Murase $\overbrace{}^{*}$ \\ Department of Materials Science and Engineering, Kyoto University, Sakyo, Kyoto 606-8501, Japan
}

\begin{abstract}
We report a novel, cyanide-free, and low-cost displacement silver (Ag) plating bath, i.e., AgCl-dissolved highly concentrated $\mathrm{CaCl}_{2} / \mathrm{LiCl}$ aqueous solution. Compared to dilute $\mathrm{CaCl}_{2} / \mathrm{LiCl}$ solutions, this aqueous solution exhibited much higher AgCl solubility because of the high activity of $\mathrm{Cl}^{-}$; the maximum $\mathrm{AgCl}$ solubility was achieved at $44.4 \mathrm{mmol} \mathrm{dm}$ (i.e., $[\mathrm{Ag}(\mathrm{I})]=8.07 \mathrm{~g} \mathrm{~kg}^{-1} \mathrm{H}_{2} \mathrm{O}$ ). Smooth Ag deposits with a lusterless gray-colored appearance were successfully obtained by displacement plating on a $\mathrm{Cu}$ substrate. The mechanism of smooth Ag plating is discussed in terms of its electrochemical and diffusive properties.

(C) The Author(s) 2019. Published by ECS. This is an open access article distributed under the terms of the Creative Commons Attribution 4.0 License (CC BY, http://creativecommons.org/licenses/by/4.0/), which permits unrestricted reuse of the work in any medium, provided the original work is properly cited. [DOI: 10.1149/2.0871910jes]

(cc) BY
\end{abstract}

Manuscript submitted March 27, 2019; revised manuscript received May 6, 2019. Published June 11, 2019.

Silver (Ag) has excellent electrical conductivity, optical reflectivity, antibacterial activity, decorative effects, and anticorrosive properties, which support its use in fields such as microelectronics, anti-bacterial applications, jewelry, and aerospace materials. ${ }^{1,2}$ Hence, electrochemical Ag plating, including electroless and displacement methods, is an industrially important process, which has been used as the final finishing process for copper wires before soldering for printed circuit boards and electronic components. ${ }^{3}$ Currently, almost all the industrial Ag electroplating baths contain inexpensive but very toxic cyanide ions as complexing agents. Without strong complexing agents such as cyanide ions, the inherent high exchange current density of $\mathrm{Ag}^{+} / \mathrm{Ag}^{0}$ redox causes dendrite formation of Ag. ${ }^{4}$ The use of cyanide baths, however, is problematic because of the threat to operator health and the increasing cost of the disposal of exhausted plating baths and wastewater treatment. Although aqueous solutions of silver nitrate $\left(\mathrm{AgNO}_{3}\right)$ have been used with ammonia as cyanide-free silver plating baths, ${ }^{5}$ they have another safety problem: fulminating silver compounds such as silver azide can be produced as a by-product.

Many studies on how to develop safe Ag plating baths have been strenuously carried out. Some aqueous Ag plating baths contain organic complexing agents including hetero-elements such as $\mathrm{C}, \mathrm{N}, \mathrm{O}$, and $\mathrm{S} .{ }^{6,7}$ These baths can cause the contamination of $\mathrm{C}, \mathrm{N}, \mathrm{O}$, and/or $\mathrm{S}$ in the Ag plating layer, and difficulty in stable operation due to changes in the concentration of additives, as organic additives can be easily decomposed chemically and/or electrochemically. Ionic liquids, which are not toxic and not volatile, have been studied for Ag plating, ${ }^{8-11}$ but they are still far from industrial use on account of their high material cost and moisture sensitivity in air. Consequently, a safe, inexpensive, and organic-free Ag plating bath has been sought.

In the present work, we investigated the electrochemical properties of $\mathrm{AgCl}$-dissolved highly concentrated metal chloride aqueous solutions of $\mathrm{CaCl}_{2}$ and $\mathrm{LiCl}$ for a novel Ag plating bath. These concentrated solutions are classified as hydrate melts, in which most of the $\mathrm{H}_{2} \mathrm{O}$ molecules are coordinated to $\mathrm{Ca}^{2+}$ or $\mathrm{Li}^{+},{ }^{12}$ while their $\mathrm{Ag}$ redox properties have been unknown.

\section{Experimental}

Preparation of the AgCl-dissolved chloride solution.-All reagents were used as purchased. To prepare a highly concentrated chloride solution, $\mathrm{CaCl}_{2}$ (95\% purity, Wako Pure Chemical Industries Ltd.) or $\mathrm{LiCl}(99.5 \%$ purity, Wako) was added to deionized water. $\mathrm{AgCl}$ (95\% purity, Wako) was added to the resulting concentrated chloride solutions with an agitation speed of $300 \mathrm{rpm}$ for $72 \mathrm{~h}$ at room temperature(RT), then the AgCl-dissolved chloride solutions were obtained. Note that the $\mathrm{AgCl}$-saturated solutions were prepared by adding an excess amount of $\mathrm{AgCl}$ and then filtering out undissolved $\mathrm{AgCl}$.

*Electrochemical Society Member.

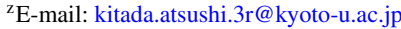

For comparison, the $\mathrm{AgNO}_{3}$-dissolved $\mathrm{Na}_{2} \mathrm{SO}_{4}$ solution was also prepared by the same procedure using $\mathrm{AgNO}_{3}$ (99.8\% purity, Wako) and $\mathrm{Na}_{2} \mathrm{SO}_{4}(98.5 \%$ purity, Wako).

Solubility of $\mathrm{AgCl}$ and viscosity of concentrated chloride solution.-The solubilities of $\mathrm{AgCl}$ in the concentrated chloride solutions were determined by measuring the $\mathrm{Ag}(\mathrm{I})$ concentration, $[\mathrm{Ag}(\mathrm{I})]$, using an inductivity coupled plasma optical emission spectrometer (ICP-OES; PSP3500, SII Nanotechnology Inc., Hitachi High-Tech Science Corporation, Tokyo). For the measurements, a matrix aqueous solution containing $0.1 \mathrm{~mol} \mathrm{dm}^{-3}$ nitric acid $(99.0 \%$, Tokyo Chemical Industry) and $0.1 \mathrm{~mol} \mathrm{dm}^{-3}$ thiourea (99.0\%, Tokyo Chemical Industry) was used to prevent the precipitation of $\mathrm{AgCl}$. The calibration curve was drawn using the standard Ag solution (1000 ppm, Wako). The viscosity of the samples was measured at RT by the viscometer (Kyoto Electronics Manufacturing, EMS-1000), and was divided by the density $(d)$ to obtain the kinematic viscosity $(v)$.

Displacement Ag plating tests.-Displacement plating tests were carried out with $1 \times 5 \mathrm{~cm}^{2} \mathrm{Cu}$ metal sheets $(0.5 \mathrm{~mm}$ thickness, Hull Cell Cathode Plates, Yamamoto-MS) as a substrate and the $\mathrm{AgCl}-$ dissolved concentrated aqueous $\mathrm{CaCl}_{2}$ solution and $\mathrm{AgNO}_{3}$-dissolved diluted $\mathrm{Na}_{2} \mathrm{SO}_{4}$ solution as plating baths. Prior to the tests, the $\mathrm{Cu}$ sheets were degreased in acetone for $15 \mathrm{~min}$ with sonication. The $\mathrm{Cu}$ sheets were soaked into the solutions for $15 \mathrm{~min}$ at RT without agitation to obtain the Ag-plated sample. During each displacement plating, the rest potential of the $\mathrm{Cu}$ sheet was measured using a potentiostat (BioLogic Science Instruments, SP-50) and a reference electrode (RE) $\mathrm{Ag} / \mathrm{AgCl}$ (Horiba 2565A) in $3.33 \mathrm{~mol} \mathrm{dm}^{-3} \mathrm{KCl}$ aqueous solution with a salt bridge. To characterize the deposits, we performed X-ray diffraction (XRD) using RIGAKU RINT2200, scanning electron microscope (SEM) observation using KEYENCE VE-7800, and energy dispersive X-ray (EDX) spectrometry using EDAX VE-9800.

Electrochemical measurements. - Voltammetry was conducted to investigate the redox behavior of the chloro-complexes of $\mathrm{Ag}$ and $\mathrm{Cu}$ in the concentrated chloride solutions at RT by the same potentiostat and RE referred before. The working electrode (WE) was a Pt, Ag, or $\mathrm{Cu}$ disk (99.95\% purity, $0.1 \mathrm{~mm}$ thickness, $10 \mathrm{~mm}$ diameter, Nilaco). Glassy carbon (Toyo Tanso) was used as the counter electrode (CE), and a glass cell of $100 \mathrm{~cm}^{3}$ capacity was used. The diffusion coefficients of $\mathrm{Ag}$ ions in the concentrated chloride solution were estimated from the linear sweep voltammograms obtained with a rotating disk electrode (RDE; Hokuto Denko, Dynamic Electrode HR-201). Prior to the measurements, WE and CE were cleaned in a diluted $0.2 \mathrm{~mol} \mathrm{dm}^{-3}$ $\mathrm{HNO}_{3}$ aqueous solution (Tokyo Chemical) for $30 \mathrm{~min}$ and degreased in acetone for $15 \mathrm{~min}$ with sonication. All electrochemical experiments were commenced after degassing the electrolyte solutions with nitrogen gas purging for $15 \mathrm{~min}$. 


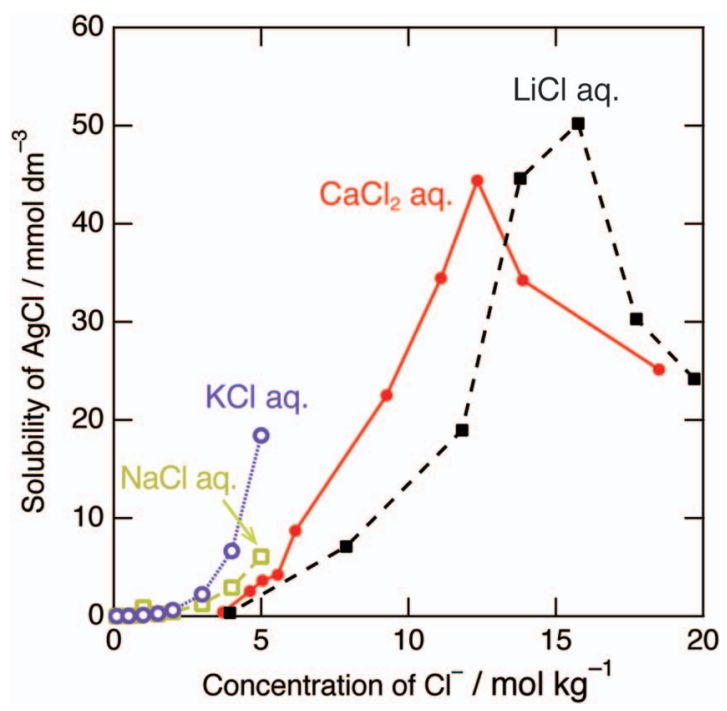

Figure 1. Solubilities of $\mathrm{AgCl}$ in $\mathrm{CaCl}_{2}$ aq. and $\mathrm{LiCl}$ aq. measured in the present work and those in $\mathrm{KCl}$ aq. and $\mathrm{NaCl}$ aq. ${ }^{12}$

\section{Results and Discussion}

Solubility of AgCl in concentrated chloride solutions.-Figure 1 shows the solubility of $\mathrm{AgCl}$ at $\mathrm{RT}$ in aqueous solutions of $\mathrm{CaCl}_{2}$ (present work), $\mathrm{LiCl}$ (present work), $\mathrm{KCl},{ }^{12}$ and $\mathrm{NaCl}^{12}$ with different $\mathrm{Cl}^{-}$concentrations. For each alkaline/alkaline earth chloride solution, the maximum $\mathrm{Cl}^{-}$concentration is near saturation. The solubility of $\mathrm{CaCl}_{2}$ and $\mathrm{LiCl}$ is much higher than that of $\mathrm{KCl}$ and $\mathrm{NaCl}$ due to the formation of hydrated melts. ${ }^{13,14}$

When compared at "relatively low" $\mathrm{Cl}^{-}$concentrations $(m<$ $5 \mathrm{~mol} \mathrm{~kg}{ }^{-1}$ ), aqueous $\mathrm{KCl}$ solutions exhibited the highest $\mathrm{AgCl}$ solubility, followed in order by $\mathrm{NaCl}, \mathrm{CaCl}_{2}$, and $\mathrm{LiCl}$ solutions. This solubility order is attributed to the decrease in $\mathrm{Cl}^{-}$activity by the larger interactions related to the ionic radius and the cation valence.

The $\mathrm{AgCl}$ solubility increased monotonically with $\mathrm{Cl}^{-}$concentration up to $\left[\mathrm{Cl}^{-}\right]=12.3 \mathrm{~mol} \mathrm{~kg}^{-1}$ for the aqueous $\mathrm{CaCl}_{2}$ solution, reaching $[\mathrm{Ag}(\mathrm{I})]=44.4 \mathrm{mmol} \mathrm{dm}{ }^{-3}$ (i.e., $[\mathrm{Ag}(\mathrm{I})]=8.07 \mathrm{~g} \mathrm{~kg}^{-1} \mathrm{H}_{2} \mathrm{O}$ ), and up to $\left[\mathrm{Cl}^{-}\right]=15.8 \mathrm{~mol} \mathrm{~kg}^{-1}$ for the aqueous $\mathrm{LiCl}$ solution, reaching $[\mathrm{Ag}(\mathrm{I})]=50.2 \mathrm{mmol} \mathrm{dm}^{-3}$ (i.e., $[\mathrm{Ag}(\mathrm{I})]=7.10 \mathrm{~g} \mathrm{~kg}^{-1} \mathrm{H}_{2} \mathrm{O}$ ). In such concentrated chloride solutions, $\mathrm{Ag}(\mathrm{I})$ species can dissolve as stable chloro-complexes $\left[\mathrm{AgCl}_{x}\right]^{(x-1)-} \cdot{ }^{12,15}$

$$
\begin{gathered}
\mathrm{Ag}^{+}+\mathrm{Cl}^{-}=\mathrm{AgCl} \\
\mathrm{AgCl}+\mathrm{Cl}^{-}=\left[\mathrm{AgCl}_{2}\right]^{-} \\
{\left[\mathrm{AgCl}_{2}\right]^{-}+\mathrm{Cl}^{-}=\left[\mathrm{AgCl}_{3}\right]^{2-}} \\
{\left[\mathrm{AgCl}_{3}\right]^{2-}+\mathrm{Cl}^{-}=\left[\mathrm{AgCl}_{4}\right]^{3-}}
\end{gathered}
$$

At higher $\mathrm{Cl}^{-}$concentrations, however, the $\mathrm{AgCl}$ solubility decreased to $[\mathrm{Ag}(\mathrm{I})]=25.1 \mathrm{mmol} \mathrm{dm}^{-3}$ at $\left[\mathrm{Cl}^{-}\right]=9.3 \mathrm{~mol} \mathrm{~kg}^{-1}$ for the aqueous $\mathrm{CaCl}_{2}$ solution and to $[\mathrm{Ag}(\mathrm{I})]=24.2 \mathrm{mmol} \mathrm{dm}^{-3}$ at $\left[\mathrm{Cl}^{-}\right]=$ $24.2 \mathrm{~mol} \mathrm{~kg}^{-1}$ for the aqueous $\mathrm{LiCl}$ solution. At such high concentrations, the solutions are overcooled at RT. For instance, the melting point at $\left[\mathrm{Cl}^{-}\right]=5.3 \mathrm{~mol} \mathrm{~kg}{ }^{-1}$ (e.g., $\mathrm{CaCl}_{2} \cdot 8.6 \mathrm{H}_{2} \mathrm{O}$ ) is $25^{\circ} \mathrm{C}$, while that at $\left[\mathrm{Cl}^{-}\right]=9.3 \mathrm{~mol} \mathrm{~kg}{ }^{-1}$ (e.g., $\mathrm{CaCl}_{2} \cdot 6 \mathrm{H}_{2} \mathrm{O}$ ) is $33^{\circ} \mathrm{C}^{16}$ Under overcooling condition, though the solution remains as liquid without forming solid structure, the degree of cation-anion dissociation should be lower. Thus, the lower activity of $\mathrm{Cl}^{-}$or the lower solubility of $\mathrm{AgCl}$ is speculated.

Consequently, the highly concentrated aqueous solutions of $\mathrm{CaCl}_{2}$ and $\mathrm{LiCl}$ exhibited an $\mathrm{AgCl}$ solubility as high as $40-50 \mathrm{mmol} \mathrm{dm}^{-3}$ (a)

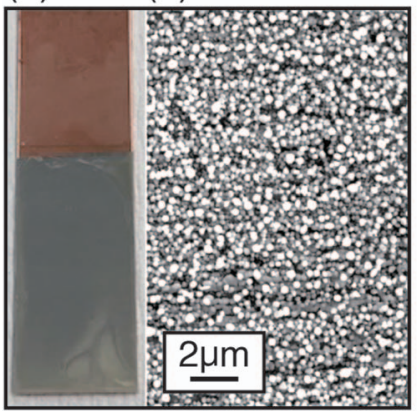

(c)

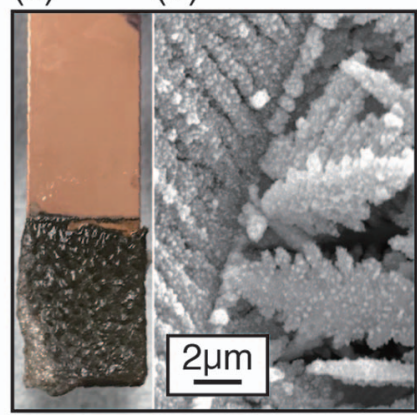

Figure 2. (a) Photograph and (b) SEM image of Ag deposits obtained on $\mathrm{Cu}$ substrate through displacement plating using $5.6 \mathrm{~mol} \mathrm{~kg}^{-1} \mathrm{CaCl}_{2}$ aq. containing $44.4 \mathrm{mmol} \mathrm{dm}^{-3} \mathrm{AgCl}$ and (c) photograph and (d) SEM image of that prepared using $0.1 \mathrm{~mol} \mathrm{~kg}^{-1} \mathrm{Na}_{2} \mathrm{SO}_{4}$ aq. containing $44.4 \mathrm{mmol} \mathrm{dm}{ }^{-3} \mathrm{AgNO}_{3}$.

at RT. Because the lowest Ag concentration in industrial plating baths

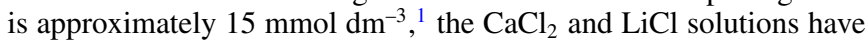
sufficient $\mathrm{AgCl}$ solubility for some $\mathrm{Ag}$ plating to be performed. Particularly, they are expected to be used for displacement plating or strike electroplating, which require similar $\mathrm{Ag}(\mathrm{I})$ concentrations in aqueous solutions. From the viewpoint of material cost, $\mathrm{CaCl}_{2}$ is more preferable than $\mathrm{LiCl}$. In the following section, we focus on the $\mathrm{AgCl}$ dissolved aqueous solution of $\mathrm{CaCl}_{2}$ for $\mathrm{Ag}$ plating.

Displacement Ag plating on $\mathrm{Cu}$ substrate.-Fig. 2a and Fig. 2b show the photograph and the SEM image, respectively, of the deposit obtained through the displacement of $\mathrm{Ag}$ plating on the $\mathrm{Cu}$ substrate using $44 \mathrm{mmol} \mathrm{dm}^{-3} \mathrm{AgCl}$-dissolved $5.6 \mathrm{~mol} \mathrm{~kg}^{-1} \mathrm{CaCl}_{2}$ aqueous solution. The immersion area was covered with gray-colored $\mathrm{Ag}$ deposit, composed of stacked submicron-diameter particles showing a smooth and lusterless surface. By contrast, as displayed in the photograph (Fig. 2c) and the SEM image (Fig. 2d), the immersion area was covered with the black-colored $\mathrm{Ag}$ deposit composed of dendritic shape in the case of displacement $\mathrm{Ag}$ plating using $44 \mathrm{mmol} \mathrm{dm}{ }^{-3} \mathrm{AgNO}_{3}$ dissolved 0.1 mol kg-1 $\mathrm{Na}_{2} \mathrm{SO}_{4}$ aqueous solution. Consequently, the Ag-chloro-complexes $\left[\mathrm{AgCl}_{x}\right]^{(x-1)-}$, formed in the concentrated chloride solution, enabled the smooth Ag plating. The XRD pattern and EDX spectrum of the deposits prepared in the $\mathrm{AgCl}$-dissolved $\mathrm{CaCl}_{2}$ aq., shown in Fig. $3 \mathrm{a}$ and in Fig. 3b, confirms that the deposit consists of crystalline $\mathrm{Ag}$ metal without trace impurities such as $\mathrm{AgCl}$, and the constituent is mainly $\mathrm{Ag}$ with a very small amount of $\mathrm{Ca}$ and $\mathrm{Cl}$.

Consequently, the AgCl-dissolved concentrated chloride aqueous solution serves as the displacement Ag plating bath that provides the Ag metal deposit with a smooth surface. The leveling of the surface is related to electrochemical properties such as the exchange current density and equilibrium potential of the redox reaction. For example, when ammonium ions coordinate to $\operatorname{Ag}(\mathrm{I})$ ions to suppress dendrite formation, the exchange current density significantly decreases. ${ }^{6}$ In addition, diffusive properties such as thickness of the diffusion layer are related to the roughness of the surface ${ }^{17}$ Below, we estimate and discuss these properties.

Cyclic voltammograms.-Cyclic voltammograms (CVs) recorded at Pt flag electrodes of $3 \mathrm{mV} \mathrm{s}^{-1}$ are shown in Fig. 4 for AgCl-dissolved $\mathrm{CaCl}_{2}$ concentrated aqueous solutions (Figs. $4 \mathrm{a}-4 \mathrm{c}$ ). For comparison, a $\mathrm{CV}$ was measured for the $\mathrm{AgNO}_{3}$ aqueous solution with $0.1 \mathrm{~mol}$ $\mathrm{kg}^{-1} \mathrm{Na}_{2} \mathrm{SO}_{4}$ as a supporting electrolyte (Fig. 4d). In all cases, the concentration of $\mathrm{Ag}(\mathrm{I})$ is $4.4 \mathrm{mmol} \mathrm{dm}{ }^{-3}$ and second-cycle CVs are shown as typical steady-state voltammograms. Each inset shows the positive-directed voltammogram near the intercept of the potential axis with which we tried to estimate the exchange current density of $\mathrm{Ag}^{+} / \mathrm{Ag}^{0}$ redox by the low-field approximation of the Butler-Volmer 
(a)

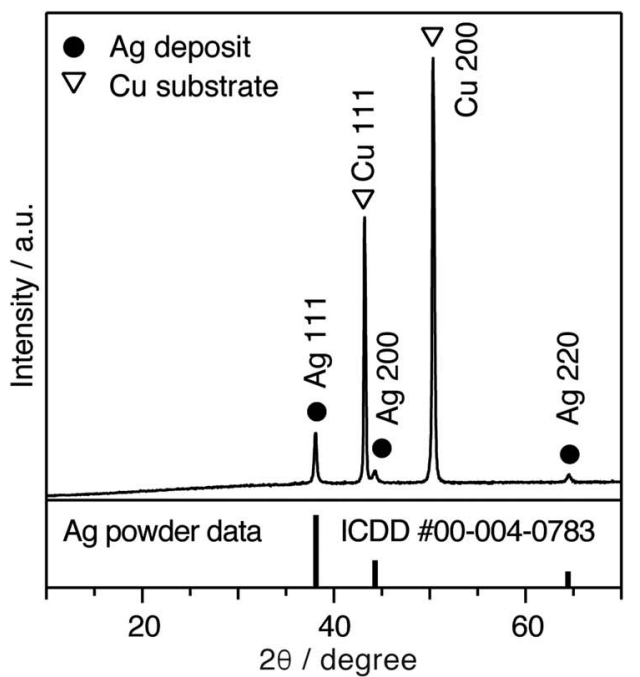

(b)

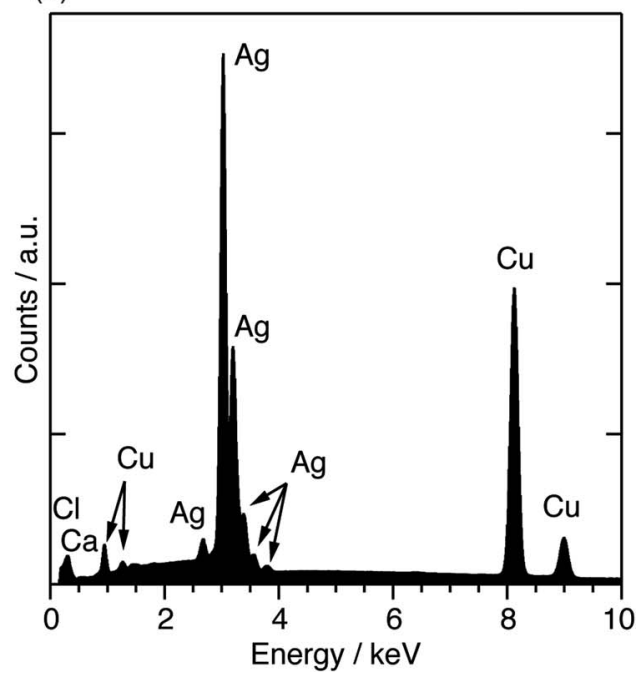

Figure 3. (a) XRD pattern and (b) EDX spectrum of Ag deposits obtained on $\mathrm{Cu}$ substrate though displacement plating using $5.6 \mathrm{~mol} \mathrm{~kg}^{-1} \mathrm{CaCl}_{2}$ aq. containing $44.4 \mathrm{mmol} \mathrm{dm}^{-3} \mathrm{AgCl}$.

equation ${ }^{18}$ as below

$$
i=-\frac{i_{0} F}{R T} \eta
$$

where $i$ is current density, $i_{0}$ is exchange current density, $F$ is the Faraday constant, $R$ is molar gas constant, $T$ is absolute temperature, and $\eta$ is overpotential. The rest potentials of the Ag electrodes, the estimated values of $i_{0}$ and the limiting current densities under static condition $i_{\lim }$ are listed in Table I. As the limiting current densities, the constant values of current densities near the switching potentials is used. Note that the estimated $i_{0}$ is not a true value because the $\mathrm{Ag}(\mathrm{I})$ concentration at the surface of the electrode is somewhat lower than that of the bulk when the potential was swept to the intercept. The $i_{0}$ calculated here, however, can be substituted to compare semiquantitatively the rate of the reaction $\mathrm{Ag} \rightarrow \mathrm{Ag}(\mathrm{I})+\mathrm{e}$.

It is revealed that the lower cathodic current was observed for the higher $\mathrm{CaCl}_{2}$ concentration. The rest potentials of $\mathrm{Ag}$ in the concentrated chloride solution were more negative than those in the $\mathrm{Cl}^{-}$-free $\mathrm{AgNO}_{3}$ solution by at least $0.35 \mathrm{~V}$, which is reasonable with the following standard electrode potentials:

$\mathrm{Ag}^{+}+\mathrm{e}=\mathrm{Ag}, \quad E^{\circ}=+0.57 \mathrm{~V} v s . \mathrm{Ag} \mid \mathrm{AgCl}$ in $3.33 \mathrm{M} \mathrm{KCl}$ aq. [6]

$$
\begin{aligned}
& {\left[\mathrm{AgCl}_{4}\right]^{3-}+\mathrm{e}=\mathrm{Ag}+4 \mathrm{Cl}^{-},} \\
& E^{\circ}=+0.22 \mathrm{~V} \text { vs. } \mathrm{Ag} \mid \mathrm{AgCl} \text { in } 3.33 \mathrm{M} \mathrm{KCl} \text { aq. }
\end{aligned}
$$

The value for Eq. 7 is calculated using the complex formation constant of $\left[\mathrm{AgCl}_{4}\right]^{3-}=\mathrm{Ag}^{+}+4 \mathrm{Cl}^{-}: \log K=6.0$. $^{15}$ The $i_{0}$ value for $9.3 \mathrm{~mol}$ $\mathrm{kg}^{-1} \mathrm{CaCl}_{2}$ was $19 \mathrm{~mA} \mathrm{~cm}$, one order of magnitude lower than that for the $\mathrm{AgNO}_{3}$ solution. The contrast of the electrochemical properties between the $\mathrm{CaCl}_{2}$ and the $\mathrm{AgNO}_{3}$ solutions is due to the increased activation energy for $\left[\mathrm{AgCl}_{x}\right]^{(x-1)-} / \mathrm{Ag}^{0}$ redox compared to that for $\left[\mathrm{Ag}\left(\mathrm{H}_{2} \mathrm{O}\right)_{n}\right]^{+} / \mathrm{Ag}^{0}$ redox.

Linear sweep voltammograms using rotating disc electrode.Figure 5 shows a set of cathodic linear sweep voltammograms using $\mathrm{Pt}$ rotating disc electrodes (RDE) voltammograms at $\mathrm{Pt}$ electrodes at $10 \mathrm{mV} \mathrm{s}^{-1}$ in $\mathrm{AgCl}$-dissolved $\mathrm{CaCl}_{2}$ concentrated aqueous solutions (Figs. 5a-5c) and the $\mathrm{AgNO}_{3}$-dissolved $\mathrm{Na}_{2} \mathrm{SO}_{4}$-diluted aqueous solution (Fig. 5d). The linear sweep voltammograms are measured at a rotating rate between 200 and $2000 \mathrm{rpm}$. The insets display the Levich plot that demonstrates the relationship between the rotating rate and the limiting current density in the RDE voltammetry. To estimate the diffusion coefficient of $\operatorname{Ag}(\mathrm{I})$ ion, the following Levich equation is used. ${ }^{19}$

$$
i_{\mathrm{L}}=0.62 z F D_{0}^{2 / 3} \omega^{1 / 2} v^{-1 / 6} c
$$

where $i_{\mathrm{L}}$ is the limiting current density, $z=1$ represents the number of electrons involved in the electrodeposition reaction, $D_{0}$ is the diffusion coefficient, $\omega$ is the angular velocity, $\nu$ is the kinematic viscosity, and $c$ is the bulk concentration of $\operatorname{Ag}(\mathrm{I})$.

The Levich plots show good linearity of the limiting current densities to the root of the angular velocities. Table II lists the kinematic viscosity, density, diffusion coefficient of $\mathrm{Ag}(\mathrm{I})$ calculated using the Levich plot, and thickness of the diffusion layer $\delta$ of $\operatorname{Ag}(\mathrm{I})$ formed during displacement $\mathrm{Ag}$ plating without agitation which are calculated by the limiting current densities measured under static condition and the concentrations of $\operatorname{Ag}(\mathrm{I})$ explained in the former section and the equation below. ${ }^{19}$

$$
\delta=\frac{z F D_{0} c}{i_{\lim }}
$$

As the $\mathrm{CaCl}_{2}$ concentration increases, the value of $\delta$ decreases by $79 \%$ with the $\mathrm{CaCl}_{2}$ concentration. This is because $D_{0}$ is much smaller than that in the solution with lower $\mathrm{CaCl}_{2}$ concentration. For example, $D_{0}=0.5 \times 10^{-6} \mathrm{~cm}^{2} \mathrm{~s}^{-1}$ for $9.3 \mathrm{~mol} \mathrm{~kg}^{-1} \mathrm{CaCl}_{2}$ electrolyte is less than one-thirtieth compared to that for the $\mathrm{AgNO}_{3}$-containing dilute solution, which is attributed to the increase in viscosity and ionic strength. The observed smooth Ag plating should be related to the decrease in the thickness of the diffusion layer. In general, elevated bath temperature and/or higher stirring rate is employed to achieve "desired" diffusion layer. ${ }^{20}$ The present work demonstrates that the thickness of the diffusion layer of $\mathrm{Ag}(\mathrm{I})$ can be decreased only by the use of a concentrated $\mathrm{CaCl}_{2}$ aqueous solution, without elevating the temperature or agitating the solution.

Determination of mixed potential for displacement Ag plating on $\mathrm{Cu}$.- To discuss the local reaction and the mixed potential of displacement $\mathrm{Ag}$ plating on $\mathrm{Cu}\left(E_{\text {mixed }}\right.$; Table III or $E_{\mathrm{a}}-E_{\mathrm{d}}$; Fig. 6), we examined the anodic dissolution of $\mathrm{Cu}$ in $\mathrm{Ag}(\mathrm{I})$-free $\mathrm{CaCl}_{2}$ and $\mathrm{Na}_{2} \mathrm{SO}_{4}$ aqueous solutions. In the chloride-free aqueous solution, $\mathrm{Cu}(\mathrm{II})$ is stable, and the displacement reaction is $2 \mathrm{Ag}^{+}+\mathrm{Cu}=2 \mathrm{Ag}+\mathrm{Cu}^{2+}$. In the concentrated chloride solution, however, $\mathrm{Cu}(\mathrm{I})$ is more stable than $\mathrm{Cu}(\mathrm{II})$ and exist as $\left[\mathrm{CuCl}_{4}\right]^{3-},{ }^{21}$ and the displacement reaction is $\mathrm{Ag}^{+}$ $+\mathrm{Cu}=\mathrm{Ag}+\mathrm{Cu}^{+}$. The half-cell reactions are as follows:

$$
\mathrm{Cu}+4 \mathrm{Cl}^{-}=\left[\mathrm{CuCl}_{4}\right]^{3-}+\mathrm{e}
$$

$$
\left[\mathrm{AgCl}_{x}\right]^{(x-1)-}+\mathrm{e}=\mathrm{Ag}+x \mathrm{Cl}^{-}
$$



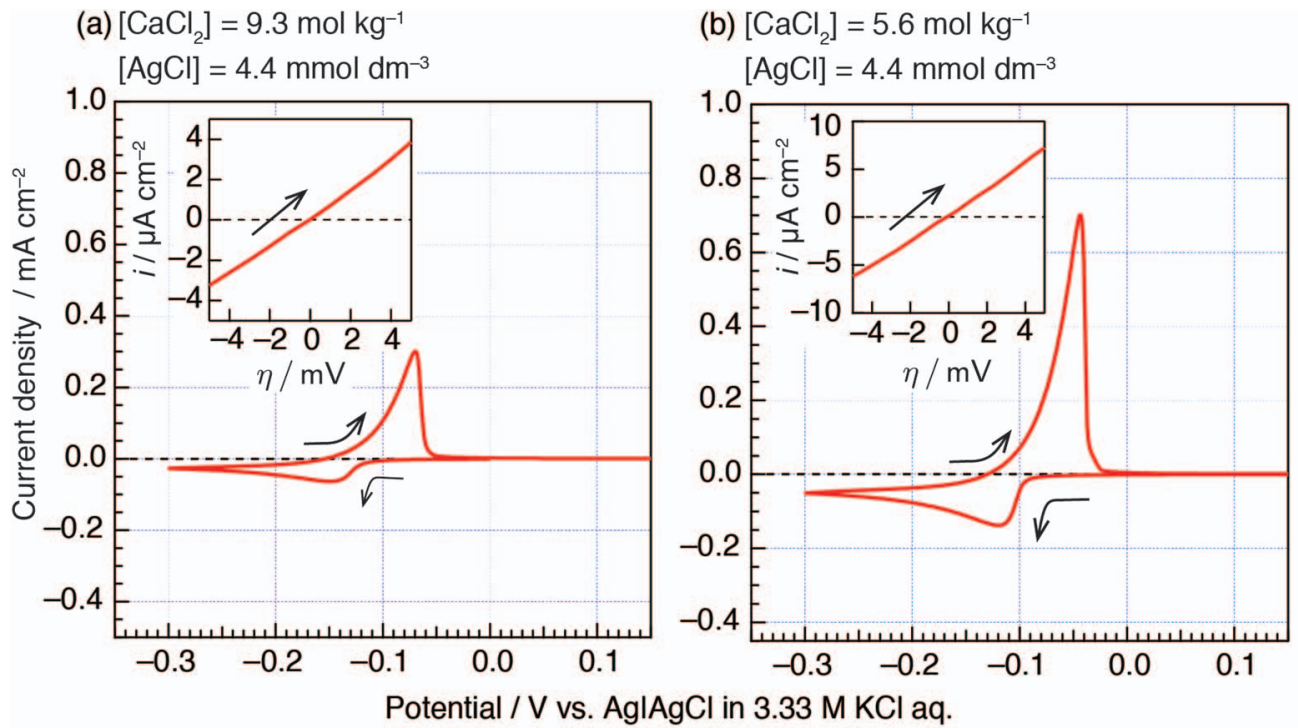

(c) $\left[\mathrm{CaCl}_{2}\right]=3.1 \mathrm{~mol} \mathrm{~kg}^{-1}$

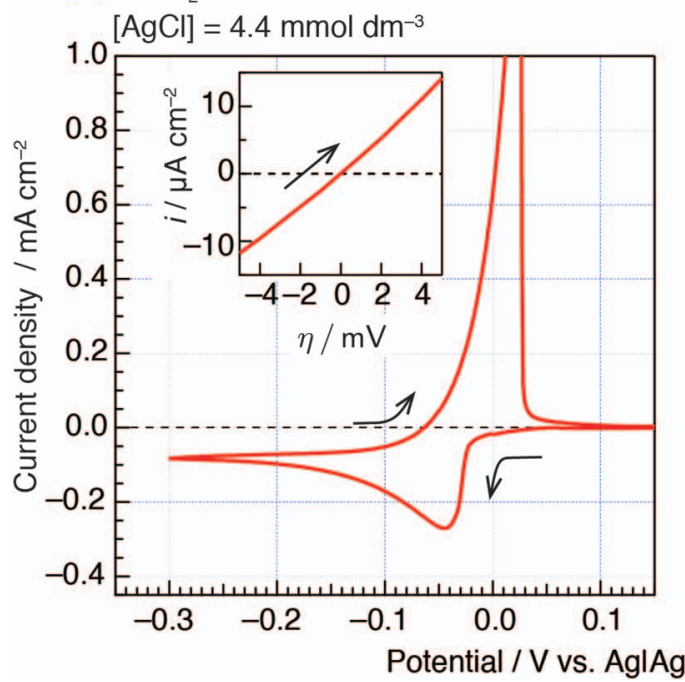

(d) $\left[\mathrm{Na}_{2} \mathrm{SO}_{4}\right]=0.1 \mathrm{~mol} \mathrm{~kg}^{-1}$

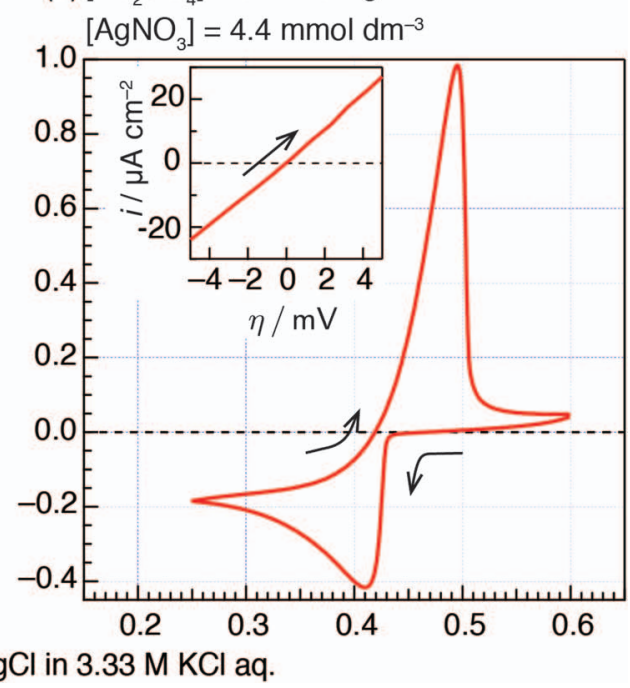

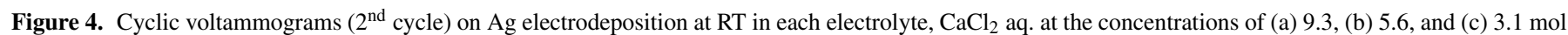

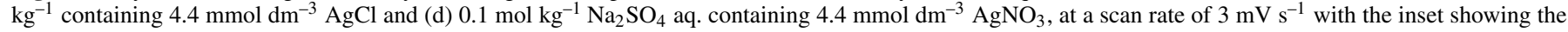
positive-directed voltammograms near the intercept of the potential axis.

Figure 6 shows a set of anodic linear sweep voltammograms for $\mathrm{Cu}$ WE in $\mathrm{CaCl}_{2}$-concentrated and $\mathrm{Na}_{2} \mathrm{SO}_{4}$-diluted aqueous solutions (Figs. 6a-6c and 6d, respectively). In the $\mathrm{CaCl}_{2}$-concentrated aqueous solutions, thought the voltammograms (Figs. 6a-6c) are similar, the redox potentials of $\mathrm{Cu}$ estimated by the intercepts are more negative at higher $\mathrm{Cl}^{-}$concentration. This fact is consistent with the Nernst
Table I. Rest potentials of $\mathrm{Ag}\left(\boldsymbol{E}_{\mathrm{Ag}}\right)$, exchange current densities $\left(i_{0}\right)$ of $\mathrm{Ag}^{+} / \mathrm{Ag}^{0}$ redox and limiting current densities $\left(i_{\lim }\right)$ in $\mathrm{CaCl}_{2}$ aq. and $\mathrm{AgNO}_{3}$ aq., containing $4.4 \mathrm{mmol} \mathrm{dm} \mathrm{mm}^{-3} \mathrm{Ag}(\mathrm{I})$ species.

\begin{tabular}{cccc}
$\begin{array}{c}\mathrm{CaCl}_{2} \\
\begin{array}{c}E_{\mathrm{Ag}} \text { (V vs. } \\
\text { oncentration } \\
\left(\mathrm{mol} \mathrm{kg}^{-1}\right)\end{array}\end{array}$ & $\begin{array}{c}\mathrm{Ag} \mid \mathrm{AgCl} \text { in } \\
3.33 \mathrm{M} \mathrm{KCl} \text { aq. })\end{array}$ & $i_{0}\left(\mathrm{~mA} \mathrm{~cm}^{-2}\right)$ & $i_{\mathrm{lim}}\left(\mathrm{mA} \mathrm{cm}^{-2}\right)$ \\
\hline 9.3 & -0.15 & 18 & -0.03 \\
5.6 & -0.13 & 34 & -0.05 \\
3.1 & -0.06 & 66 & -0.08 \\
0 & +0.42 & 126 & -0.19
\end{tabular}

equation. However, the redox potentials of $\mathrm{Cu}$ in the $\mathrm{Na}_{2} \mathrm{SO}_{4}$-diluted aqueous solution were much more negative than that by $0.4 \mathrm{~V}$ (Fig. 6d). This is attributed to the fact that $\mathrm{Cu}$ dissolves as $\mathrm{Cu}(\mathrm{I})$ in the chloride solution, while $\mathrm{Cu}$ dissolves as $\mathrm{Cu}$ (II) aquo-ion in the chloride-free solution.

Table II. The properties related to the diffusion of $\mathrm{Ag}^{+}$in $\mathrm{CaCl}_{2}$ aq. at each concentration: kinematic viscosity $(v)$, density $(d)$, diffusion coefficient $\left(D_{0}\right)$ of $\operatorname{Ag}(I)$, and the estimated thickness of diffusion layer $(\delta)$ during the electrodeposition of $\mathrm{Ag}$ without agitation.

$\mathrm{CaCl}_{2}$ con-

centration

$\left(\mathrm{mol} \mathrm{kg}^{-1}\right) \quad \nu\left(\mathrm{mm}^{2} \mathrm{~s}^{-1}\right) \quad d\left(\mathrm{~g} \mathrm{~cm}^{-3}\right) \quad D_{0}\left(10^{-6} \mathrm{~cm}^{2} \mathrm{~s}^{-1}\right) \quad \delta(\mu \mathrm{m})$

\begin{tabular}{ccccc}
\hline 9.3 & 20.20 & 1.47 & 0.5 & 7.8 \\
5.6 & 4.48 & 1.34 & 1.5 & 12.5 \\
3.1 & 2.50 & 1.24 & 3.7 & 18.8 \\
0 & 1.09 & 1.01 & 16.1 & 36.9
\end{tabular}


(a) $\left[\mathrm{CaCl}_{2}\right]=9.3 \mathrm{~mol} \mathrm{~kg}^{-1}$

$[\mathrm{AgCl}]=4.4 \mathrm{mmol} \mathrm{dm}^{-3}$

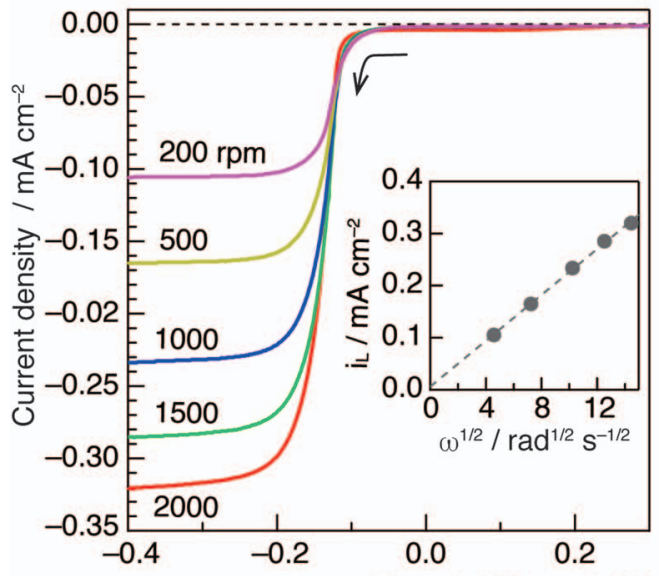

(b) $\left[\mathrm{CaCl}_{2}\right]=5.6 \mathrm{~mol} \mathrm{~kg}^{-1}$

$[\mathrm{AgCl}]=4.4 \mathrm{mmol} \mathrm{dm}^{-3}$

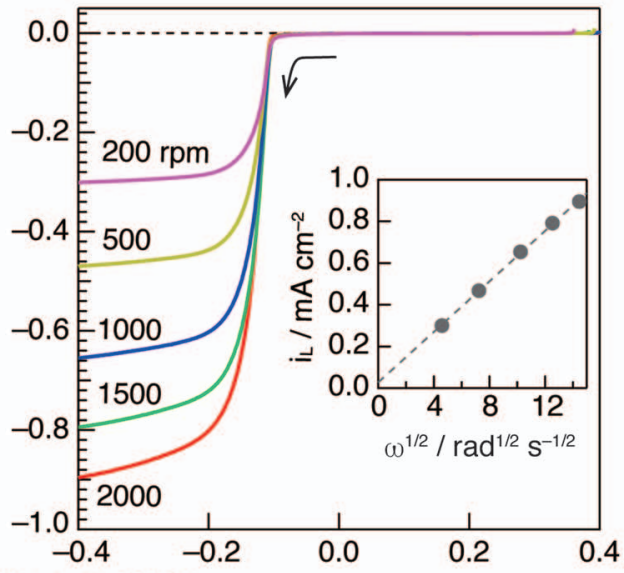

Potential / V vs. AglAgCl in $3.33 \mathrm{M} \mathrm{KCl}$ aq.

(c) $\left[\mathrm{CaCl}_{2}\right]=3.1 \mathrm{~mol} \mathrm{~kg}^{-1}$

$[\mathrm{AgCl}]=4.4 \mathrm{mmol} \mathrm{dm}^{-3}$

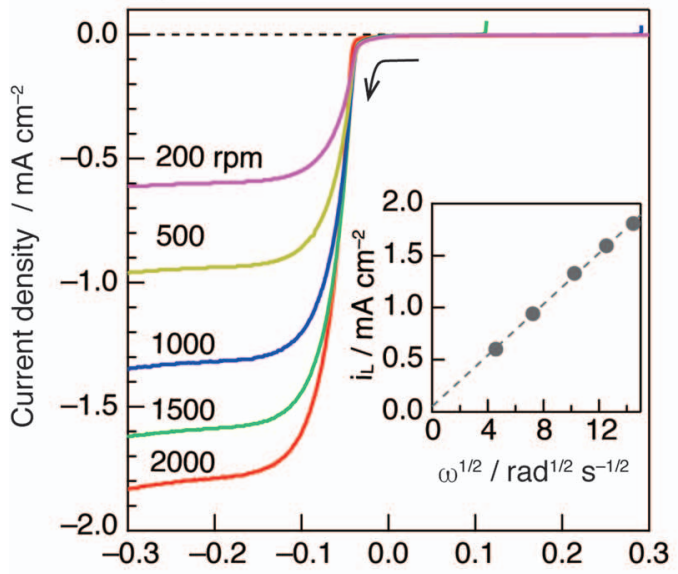

(d) $\left[\mathrm{Na}_{2} \mathrm{SO}_{4}\right]=0.1 \mathrm{~mol} \mathrm{~kg}^{-1}$

$\left[\mathrm{AgNO}_{3}\right]=4.4 \mathrm{mmol} \mathrm{dm}^{-3}$

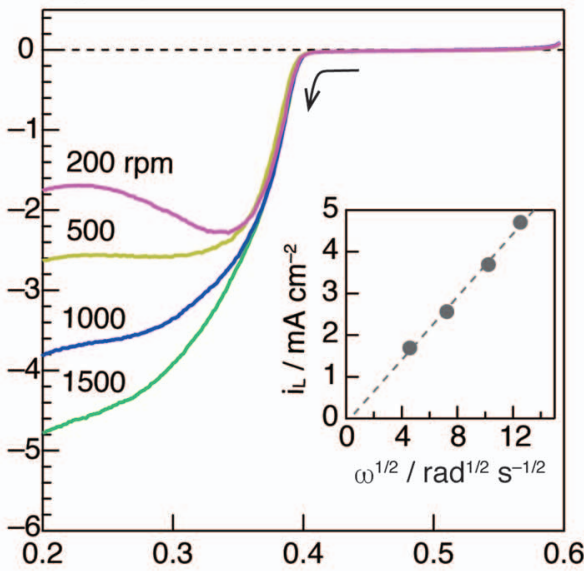

Potential / V vs. AglAgCl in $3.33 \mathrm{M} \mathrm{KCl}$ aq.

Figure 5. A set of voltammograms on $\mathrm{Ag}$ electrodeposition using platinum rotating disc electrode at $\mathrm{RT}$ in each electrolyte, $\mathrm{CaCl}_{2}$ aq. at the concentrations of (a) 9.3 , (b) 5.6 , and (c) $3.1 \mathrm{~mol} \mathrm{~kg} \mathrm{k}^{-1}$ containing $4.4 \mathrm{mmol} \mathrm{dm}{ }^{-3} \mathrm{AgCl}$ and (d) $0.1 \mathrm{~mol} \mathrm{~kg}^{-1} \mathrm{Na}_{2} \mathrm{SO}_{4}$ aq. containing $4.4 \mathrm{mmol} \mathrm{dm}^{-3} \mathrm{AgNO}_{3}$ at a scan rate of $10 \mathrm{mV} \mathrm{s}^{-1}$ and at several rotating rates with the inset showing Levich plots.

A set of cathodic voltammograms for Ag electrodeposition (see Fig. 4) are also reshown in Fig. 6. The mixed potentials $E_{\text {mixed }}$ are indicated as $E_{\mathrm{a}}-E_{\mathrm{d}}$, at which the cathodic current and the anodic current are equal. ${ }^{22}$ Table III summarizes the estimated mixed potentials $\left(E_{\text {mixed }}\right.$, or $\left.E_{\mathrm{a}}-E_{\mathrm{d}}\right)$ and the overpotentials $(\eta)$ of the reduction of $\mathrm{Ag}(\mathrm{I})$ that is calculated by $\eta=E_{\mathrm{Ag}}-E_{\text {mixed }}$ (see Table I). The rest potentials of $\mathrm{Cu}$ monitored during displacement $\mathrm{Ag}$ plating $\left(E_{\text {rest, } \mathrm{Cu}}\right)$ are simi-

\begin{tabular}{|c|c|c|}
\hline \multicolumn{3}{|c|}{$\begin{array}{l}\text { Table III. The mixed potentials }\left(E_{\text {mixed }}\right) \text { and overpotentials of } \\
\text { the Ag reduction reaction }(\eta) \text { during displacement } \mathrm{Ag} \text { plating on } \\
\mathrm{Cu} \text { substrate in } \mathrm{CaCl}_{2} \text { aq. containing } 4.4 \mathrm{mmol} \mathrm{dm}^{-3} \mathrm{AgCl} \text { and } \\
\mathrm{Na}_{2} \mathrm{SO}_{4} \text { aq. containing } 4.4 \mathrm{mmol} \mathrm{dm} \mathrm{AgNO}_{3} \text {. }\end{array}$} \\
\hline \multicolumn{3}{|c|}{$\begin{array}{ccc}\mathrm{CaCl}_{2} & E_{\text {mixed }}(\mathrm{V} \text { vs. } & \\
\text { concentration } & \mathrm{Ag} \mid \mathrm{AgCl} \text { in } & \\
\left(\mathrm{mol} \mathrm{kg}^{-1}\right) & 3.33 \mathrm{M} \mathrm{KCl} \text { aq. }) & \eta(\mathrm{V})\end{array}$} \\
\hline 9.3 & & 0.18 \\
\hline 5.6 & $E_{\mathrm{b}},-0.31$ & 0.18 \\
\hline 3.1 & $E_{\mathrm{c}},-0.28$ & 0.22 \\
\hline 0 & & 0.34 \\
\hline
\end{tabular}

lar to the values of $E_{\text {mixed }}$, although $E_{\text {rest, Cu }}$ was measured in the case of $[\mathrm{Ag}(\mathrm{I})]=44.4 \mathrm{mmol} \mathrm{dm}^{-3}$ and $E_{\text {mixed }}$ was estimated in the case of $[\mathrm{Ag}(\mathrm{I})]=4.4 \mathrm{mmol} \mathrm{dm}^{-3}$. As results, $E_{\text {rest, } \mathrm{Cu}}=-0.23 \mathrm{~V}$ and $E_{\text {mixed }}=-$ $0.31 \mathrm{~V}$ for $5.6 \mathrm{~mol} \mathrm{~kg}^{-1} \mathrm{CaCl}_{2}$ aqueous solution and $E_{\text {rest }, \mathrm{Cu}}=+0.13 \mathrm{~V}$ and $E_{\text {mixed }}=+0.04 \mathrm{~V}$ in $0.1 \mathrm{~mol} \mathrm{~kg} \mathrm{~kg}_{2} \mathrm{SO}_{4}$ aqueous solution. In $\mathrm{CaCl}_{2}$-concentrated aqueous solutions, the overpotential $\eta$ is $+0.18 \mathrm{~V}$ and $+0.22 \mathrm{~V}, 0.12-0.16 \mathrm{~V}$ lower than that in the $\mathrm{Na}_{2} \mathrm{SO}_{4}$-diluted aqueous solution, $\eta=+0.34 \mathrm{~V}$. Reduction in overpotential is one of the common mechanisms of leveling deposit for other Ag plating baths. ${ }^{5}$

Finally, we would like to discuss the mechanism of smooth $\mathrm{Ag}$ plating in terms of its electrochemical and diffusive properties. Similar to the case of ammonia baths, ${ }^{6}$ strong complexation of $\mathrm{Ag}^{+}$occurs to cause significant decrease in the exchange current density and overpotential. Compared with the diluted aqueous solution, the exchange current density is one order of magnitude smaller and the overpotential of $\mathrm{Ag}$ reduction is $0.12-0.16 \mathrm{~V}$ lower in the case of the $\mathrm{CaCl}_{2}$ concentrated aqueous solutions. We would stress, however, that a line should be drawn between the previous and present baths in terms of their diffusive properties. That is to say, a very small diffusion coefficient $\left(0.5 \times 10^{-6} \mathrm{~cm}^{2} \mathrm{~s}^{-1}\right)$ causes a $79 \%$ decrease in the thickness of the diffusion layer, which should be specific to the concentrated $\mathrm{CaCl}_{2}$ baths. We would also like to note that, since the diffusive properties 


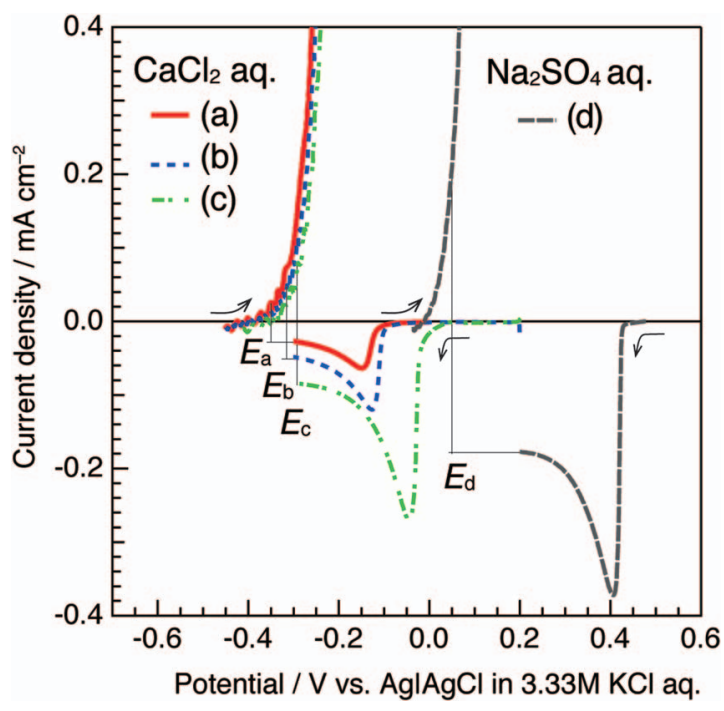

Figure 6. Linear-sweep voltammograms for $\mathrm{Cu}$ anodic dissolution at RT in each electrolyte, $\mathrm{CaCl}_{2}$ aq. at the concentrations of (a) 9.3, (b) 5.6, and (c) $3.1 \mathrm{~mol} \mathrm{~kg}^{-1}$ and (d) $0.1 \mathrm{~mol} \mathrm{~kg}^{-1} \mathrm{Na}_{2} \mathrm{SO}_{4}$ aq., at scan rate of $3 \mathrm{mV} \mathrm{s}^{-1}$. Negative-directed voltammograms on $\mathrm{Ag}$ electrodeposition, which have been shown in Fig. 4, are imposed to determine the mixed potentials $E_{\mathrm{a}}-E_{\mathrm{d}}$ (see text for details).

of $\mathrm{Ag}$ ions can be affected by $\mathrm{Cu}$ species during displacement plating, further study on the local profile of $\mathrm{Ag}(\mathrm{I})$ concentration near the electrode is of interest.

\section{Conclusions}

Using a concentrated calcium chloride solution that can sufficiently dissolve $\mathrm{AgCl}$, smooth $\mathrm{Ag}$ coating on $\mathrm{Cu}$ was successful, which demonstrates the properties as a novel cyanide-free displacement Ag plating bath. The electrochemical properties of the redox reaction of $\mathrm{Ag}$-chloro-complexes $\left[\mathrm{AgCl}_{x}\right]^{(x-1)-}$ are revealed. For redox of $\left[\mathrm{AgCl}_{x}\right]^{(x-1)-}$, its exchange current density and overpotential is lower than that for the redox of $\mathrm{Ag}^{+}$aquo-ion. Additionally, the diffusion coefficient of $\left[\mathrm{AgCl}_{x}\right]^{(x-1)-}$ is low, which decreases the thickness of the diffusion layer. These properties can contribute to the absence of dendrite formation. For practical or industrial utilization, further studies on the morphology of the surface and the effect of additives, such as a leveler or brighter, may be required to obtain a highly flat or mirror-like surface.

\section{Acknowledgments}

This work was supported financially by Grants-in-Aid for Scientific Research (B) (No. 19H02490: A. K.) from the Japan Society for the Promotion of Science (JSPS).

\section{ORCID}

Ken Adachi (i) https://orcid.org/0000-0001-7058-9672

Atushi Kitada (D) https://orcid.org/0000-0002-4387-8687

Kuniaki Murase (D) https://orcid.org/0000-0002-7564-9416

\section{References}

1. M. Schlesinger, Modern Electroplating, p. 131, John Wiley \& Sons, New York, NY (2011).

2. G. O. Mallory and J. B. Hajdu, Electroless plating: fundamentals and applications, p. 441, American Electroplaters and Surface Finishers Society, Orland, FL (1990).

3. J. Kenny, K. Wengenroth, T. Antonellis, S. Kawashima, and M. Nagakura, J. Surf. Finish. Soc. Jpn., 59, 589 (2008).

4. N. A. Shumilova and G. V. Zhutaeva, Encyclopedia of electrochemistry of the elements, (Ed. by A. J. Bard,), Marcel Dekker, New York, NY (1978).

5. S. Arai and J. Fujii, J. Electrochem. Soc., 158, D506 (2011).

6. K. I. I. Popov, N. V. V. Krstajić, and S. R. R. Popov, Surf. Technol., 20, 203 (1983).

7. H. Inoue, K. Yamakawa, and S. Masaki, J. Surf. Finish. Soc. Jpn., 44, 402 (1993).

8. R. Bomparola, S. Caporali, A. Lavacchi, and U. Bardi, Surf. Coat. Technol., 201, 9485 (2007).

9. A. Basile, A. I. Bhatt, A. P. O'Mullane, and S. K. Bhargava, Electrochim. Acta, 56, 2895 (2011)

10. S. Zein El Abedin and F. Endres, Electrochim. Acta, 54, 5673 (2009).

11. B. H. R. Suryanto, C. A. Gunawan, X. Lu, and C. Zhao, Electrochim. Acta, 81, 98 (2012).

12. A. A. Chialvo and J. M. Simonson, J. Chem. Phys., 119, 8052 (2003)

13. J. A. Rard and S. L. Clegg, J. Chem. Eng. Data, 42, 819 (1997).

14. L. Greenspan, J. Res. Natl. Bur. Stand. Phys. Chem., 81, 89 (1977).

15. R. M. Smith and A. E. Martell, Critical Stability Constants, p. 104, Springer US, Boston, MA, (1976).

16. T. Yamaguchi, S. Hayashi, and H. Ohtaki, Inorg. Chem., 28, 2434 (1989).

17. A. R. Despić and K. I. Popov, in Modern Aspects of Electrochemistry No. 7, p. 199, Springer US, Boston, MA (1972).

18. V. S. Bagotsky, Fundamentals of electrochemistry, 2nd ed., p. 87, John Wiley \& Sons, New York, NY (2005).

19. A. J. Bard and L. R. Faulkner, Electrochemical methods : fundamentals and applications, 2nd ed., p. 339, John Wiley \& Sons, New York, NY (2000).

20. N. Kanani, Electroplating : basic principles, processes and practice, p. 134, Elsevier, NL (2004).

21. R. W. Revie, Corrosion and Corrosion Control: An Introduction to Corrosion Science and Engineering, 4th ed., p. 367, John Wiley \& Sons, New York, NY (2008).

22. I. Ohno, Surf. Technol., 4, 515 (1976). 